\title{
LA FACTURA ELECTRÓNICA. UN CASO DE ANÁLISIS DEL PRINCIPIO DE EQUIVALENCIA FUNCIONAL PARA EL DERECHO CHILENO
}

\author{
THE ELECTRONIC INVOICE. AN ANALISYS CASE OF \\ THE PRINCIPAL OF FUNCTIONAL EQUIVALENCE FOR \\ CHILEAN LAW
}

MAXIMILIANO ESCOBAR SAAVEDRA*

Prof. de Derecho Comercial

Universidad de Concepción

Concepción - Chile

\section{RESUMEN}

El propósito de este trabajo es analizar los efectos que, respecto de un título en particular, la factura, se producen a partir de la dictación de la Ley 20.727 (por la cual se estableció como principio general la obligatoriedad de su emisión en forma electrónica, dando lugar a la factura electrónica), y entender cómo el cambio de soporte documental afecta el régimen de emisión y cesión de la copia cedible, y al cobro ejecutivo del crédito consagrado en ella, regulado por el legislador en la Ley 19.983.

Palabras clave: Factura electrónica; título de crédito; electronificación; abstracción; equivalencia funcional.

* Abogado. Profesor de Derecho Comercial, Universidad de Concepción. Doctor en Derecho, Universidad Pablo de Olavide, Sevilla, España. Correo electrónico: maxescob@udec.cl. Artículo recibido el 26 de junio de 2017, y aceptado para su publicación el 22 de noviembre de 2017. 


\section{ABSTRACT}

The purpose of this work is to analyze the effects that, on a particular title, the invoice, are produced from the enactment of Law 20.727 (by which it was established, as a general principle, the obligatory nature of its issuance in electronic form, giving rise to electronic invoicing), and understand how the change in documentary support affects the regime of issuance and transfer of the assignable copy, and the executive collection of the credit contained in it, regulated by the legislator in Law 19.983 .

Keywords: Electronic invoice; credit title; electronification; abstraction; functional equivalence.

\section{INTRODUCCIÓN}

Los títulos valores, esto es, aquellos documentos que llevan incorporado un derecho literal y autónomo que se puede ejercer por el portador legítimo contra el deudor a la fecha de su vencimiento, ${ }^{1}$ requieren de elementos estructurales, soporte material y declaración documental, que les permitan desarrollar en forma efectiva las aptitudes probatorias, constitutivas y dispositivas que les son inherentes.

Estas propiedades derivan del aspecto formal de los títulos valores, es decir, de aquella circunstancia esencial de haberse respetado las normas de emisión, literalidad y transferencia que sean propias según el título que se trate, resultando indispensable para ello el documento en que este conste.

El propósito de este trabajo es analizar los efectos que, respecto de un título en particular, la factura, se producen a partir de la Ley $20.727^{2}$ (por la cual se estableció como principio general la obligatoriedad de su emisión en forma electrónica, dando lugar por tanto a la factura electrónica), ${ }^{3}$ y ponderar acerca de cómo el cambio de soporte documental afecta el régimen de emisión

1 Sandoval López, Ricardo, Derecho Comercial. Tomo II, Teoría General de los Títulos Valores, Editorial Jurídica de Chile, Santiago, 2015, pp. 17, 18.

2 Ley 20.727, D. Oficial de 31 de enero de 2014.

3 "Factura electrónica: Facturas de venta, facturas de compra, facturas exentas y liquidaciones factura, generadas como un documento electrónico emitido y firmado por un contribuyente autorizado por el Servicio de Impuestos Internos", Art. 1 a), D.S. 93, por el que se aprueba reglamento para la aplicación del artículo noveno de la Ley $\mathrm{N}^{\circ} 19.983$, respecto de la cesión de los créditos contenidos en una factura electrónica. Decreto Supremo 93, D. Oficial de 13 de abril de 2005. 
y cesión de la copia cedible, y del cobro ejecutivo del crédito consagrado en ella, regulado por el legislador en la Ley $19.983 .{ }^{4}$

\section{ANTECEDENTES NORMATIVOS PARA LA DISCUSIÓN}

Sin perjuicio que, como hemos enunciado, fue la Ley 20.727 (art. $1.2)^{5}$ el estatuto normativo que vino a establecer la obligación de emitir a la factura de manera electrónica al disponer que: "las facturas, facturas de compra, liquidaciones facturas y notas de débito y crédito que deban emitir los contribuyentes, consistirán exclusivamente en documentos electrónicos emitidos en conformidad a la ley, sin perjuicio de las excepciones legales pertinentes", no se puede soslayar que la Ley 19.983 (art. $9^{\circ}$, inc. $1^{\circ}$, primera parte) ya desde el año 2004 reconocía la posibilidad de la desmaterialización del título, al disponer que: "Las normas de la presente ley serán igualmente aplicables en caso que la factura sea un documento electrónico emitido de conformidad a la ley por un contribuyente autorizado por el Servicio de Impuestos Internos". Con todo, el referido artículo $9^{\circ}$ no hacía sino reconocer en la Ley lo que el Ordenamiento ya permitía, a partir de la incorporación a nuestro derecho del principio de equivalencia funcional en la Ley 19.799 (en adelante, LFE). ${ }^{6}$

En efecto, la emisión electrónica de la factura, incluso aún antes de dictarse la Ley $19.983,{ }^{7}$ contaba con amplia normativa de sustento (principalmente administrativa), que ya toleraba y promovía su uso. En tal sentido encontramos, por ejemplo, a la Resolución Exenta $\mathrm{N}^{\circ} 14$, del 8 de febrero de 2005 del Servicio de Impuestos Internos (SII), ${ }^{8}$ el Decreto $\mathrm{N}^{\circ} 93$ del 13 de abril de 2005 del Ministerio de Hacienda, ${ }^{9}$ la Circular 56 del 27 de

${ }^{4}$ Ley 19.983, D. Oficial de 15 de diciembre de 2004, modificada, entre otras, por las Leyes $\mathrm{N}^{\circ} 20.323$ y 20.956 , de 29 de enero de 2009 y de 26 de octubre de 2016 respectivamente.

5 Por dicho precepto se modifica el art. $54^{\circ}$ de la Ley sobre Impuesto a las Ventas y Servicios, contenida en el Decreto Ley No 825, de 1974.

${ }^{6}$ Artículos $1^{\circ}$ y $3^{\circ}$ de la le Ley 19.799 sobre documentos electrónicos, firma electrónica y servicios de certificación de dicha firma, D. Oficial de 12 de abril de 2002.

7 En efecto el SII dictó con fecha 1 de septiembre de 2003 la Resolución Exenta $N^{\circ} 45$ por la que estableció normas y procedimientos de operación respecto de los documentos tributarios electrónicos.

8 Resolución Exenta $N^{\circ}$ 14, del 8 de febrero de 2005 del Servicio de Impuestos Internos, por la que se estableció normas y procedimientos de operación respecto de los documentos tributarios electrónicos.

9 Decreto $\mathrm{N}^{\circ} 93$ del 13 de abril de 2005 del Ministerio de Hacienda, por el que se aprobó el reglamento para la aplicación del art. $9^{\circ}$ de la Ley 19.983, respecto de la cesión de los créditos contenidos en una factura electrónica. 
noviembre de 2013 del SII, ${ }^{10}$ entre otras.

No obstante lo indicado, es a partir de la entrada en vigencia de la Ley 20.727 y de la normativa del SII que fija como calendario de aplicación para los casos ella contemplados el 1 de enero de $2018,{ }^{11}$ que entendemos necesario estudiar, desde la dogmática jurídica, cómo estas normas que obligan al cambio de soporte (de uno tradicional en papel a uno electrónico), se relacionan de forma adecuada con aquellas que regulan aspectos fundamentales de dicho título, como son: i) la capacidad probatoria de la factura de dar cuenta del estado de pago o remuneración de una operación de venta, de una prestación de servicios o en aquellas que la ley asimile a tales operaciones (art. $1^{\circ}$ Ley 19.983); ii) la aptitud de constituir, por medio de la factura un derecho para su titular, en cuanto se cumplan las formalidades que deben observarse para su emisión, eventual cesibilidad, y posterior mérito ejecutivo (arts. $1^{\circ}, 3^{\circ}$, $4^{\circ}, 5^{\circ}, 7^{\circ}$, Ley 19.983 ); y muy especialmente, iii) su potencial para que la transferencia del crédito contenido en ella, ya sea en propiedad o en comisión de cobranza, y que de acuerdo al Ordenamiento se realiza, en el caso de la factura electrónica, a través de la cesión electrónica del crédito (art. $9^{\circ}$ inc. $2^{\circ}$, Ley 19.983), ${ }^{12}$ se repute perfecta, de forma que permita al título cumplir con su aptitud dispositiva, aun cuando la factura electrónica se encuentre contenida ya no en un soporte material físico, sino que en uno electrónico cuya principal característica es la intangibilidad. ${ }^{13}$

\footnotetext{
${ }^{10}$ Circular N $\mathrm{N}^{\mathrm{0}} 56$ del 27 de noviembre de 2013 del SII, impartió instrucciones sobre cesión de créditos contenidos en una factura electrónica y estableció el procedimiento de anotaciones correcciones o revocaciones de anotaciones en el Registro Público Electrónico de Transferencias de Créditos.

${ }^{11}$ Véase a este respecto material informativo del SII sobre certificado digital y obligatoriedad de la factura electrónica, disponible en línea: http://www.sii.cl/material_inf/obligatoriedad_FE.pdf, visita del 2 de noviembre de 2017.

${ }^{12}$ Ley 19.983, art. $9^{\circ}$ inc. $2^{\circ}$ : "Sin perjuicio de lo señalado en el artículo $7^{\circ}$, la cesión del crédito expresado en estas facturas solamente podrá efectuarse mediante medios electrónicos y se pondrá en conocimiento del obligado al pago de ellas, mediante su anotación en un registro público electrónico de transferencias de créditos contenidos en facturas electrónicas que llevará el Servicio de Impuestos Internos. Se entenderá que la transferencia ha sido puesta en conocimiento del deudor el día hábil siguiente a aquel en que ella aparezca anotada en el registro señalado. El Servicio de Impuestos Internos podrá encargar a terceros la administración del registro".

${ }^{13}$ En efecto podemos suponer perfectamente que la intención del legislador en torno a la regulación de la factura electrónica, no fue prescindir de ella como documento, sino que por el contrario, el objetivo ha sido mantenerse actualizado con el desarrollo de la tecnología, de manera de otorgar a los comerciantes instrumentos adecuados que facilitaren el desenvolvimiento de sus actividades comerciales.
} 


\section{LOS TÍTULOS VALORES INFORMÁTICOS, ELECTRÓNICOS O TELEMÁTICOS COMO FUNDAMENTO DOGMÁTICO DEL ANÁLISIS}

Aparte del problema que suscita la noción de título valor, los elementos de su estructura y la imposibilidad de incluir dentro del concepto cierto número de títulos que se emplean en la actividad mercantil, se ha planteado desde un tiempo a esta parte la cuestión que la masificación del número de documentos que se emiten genera dificultades en el manejo de ese enorme volumen y el costo que ello implica.

Gracias al empleo de la informática, se puede lograr que los títulos de crédito emitidos en forma telemática cumplan su función en la circulación, esto es, que se produzca el traspaso de los derechos en ellos representados, no obstante que el título permanezca inmovilizado, es decir, puede circular el derecho contenido en el título, sin que éste se transfiera materialmente.

Lo anterior es posible, por cuanto, a partir de la emisión de los títulos en forma electrónica, la conexión permanente o el consorcio indisoluble entre los elementos de un título valor, esto es el sustrato material o documento y la declaración de contenido obligacional o derecho representado en el título, deja de ser relevante, toda vez que con el empleo de la informática éste se electronifica, vale decir, se omite el soporte material o documento sobre papel. ${ }^{14}$

En la estructura tradicional de un título valor, esto es, soporte material o bien mueble y relación obligacional de contenido económico que se representa en el documento, el documento no sólo acredita la existencia y contenido de un derecho, sino que lo constituye y sirve para su transferencia. A partir de lo anterior podemos señalar que en su contenido literal estos títulos incorporan o materializan un derecho. Como el derecho se encuentra incorporado, es necesario poseer el documento para ejercerlo, por lo tanto, cualquier transferencia de éste, también conlleva la transferencia del derecho que ahora se ha materializado.

${ }^{14}$ Sandoval López, Ricardo, Derecho Comercial, Teoría General de los Títulos de Crédito, Letra de Cambio, Pagaré, Cheque y Títulos Electrónicos o Desincorporados, Editorial Jurídica de Chile,

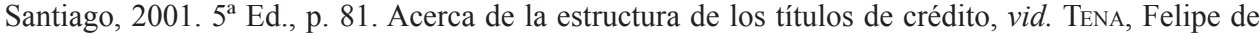
J., Títulos de Crédito, Editorial Porrúa, México 1956, p.16 y siguientes. En el origen de la idea de la incorporación del derecho al título valor, se encuentra la teoría de la propiedad alemana para explicar que el propietario de un título valor fuera titular del derecho en el representado, afirmación que puede resultar excesiva, pues el papel sólo es instrumento al que se anudan los efectos legitimatorios propios de la protección a que se vincula la posesión de un bien mueble. ReCALDE CASTELLS, Andrés, "Electronificación de los títulos-valor", en: Fernández Ordóñez, M.; Cremades García, J.; Illescas Ortiz, R. (coords.), Régimen Jurídico de Internet, Editorial La Ley, España, 2001, p. 571. 
Debemos enfatizar que el derecho contenido en el título siempre es intangible, por ello es que debió idearse una forma de lograr su materialización en un soporte. Tal objetivo se logra incorporándolo en un documento, que tradicionalmente ha sido el papel. De este modo, es posible concluir que lo intangible, el derecho, al ser legalmente incorporado al soporte, que siempre es material o apreciable por los sentidos, se constituye en un bien tangible, se convierte por lo tanto en "cosa".

La construcción anteriormente descrita, elaborada y desarrollada durante el tiempo, permitió agilizar al comercio, dándole un tratamiento de cosas muebles a derechos que no tenían una existencia física y deberemos tenerla presente al momento de analizar los títulos de crédito electrónicos o desincorporados.

A partir de la electronificación ${ }^{15}$ de los títulos valores, la estructura tradicional de éstos se ve afectada desde que ya no es necesario un papel para disponer de un derecho, sino que bastará una mera representación telemática para lograrlo, produciéndose con ello la desincorporación del título, y haciendo que el derecho en él representado pueda circular sólo por medio de una anotación contable. ${ }^{16}$

La desmaterialización o sustitución del soporte papel como soporte de los derechos tradicionalmente incorporados en títulos valores se ha manifestado, sobre todo, en los títulos del transporte, y los valores mobiliarios negociados en los mercados de valores, ${ }^{17}$ mas este fenómeno, al día de hoy, alcanza a otras

\footnotetext{
${ }^{15}$ Definida a propósito del contrato de transporte, como: "aquél fenómeno económico y jurídico, de creciente e imparable difusión, mediante el que la forma tradicional en papel mecano o autografiado de celebración y documentación del contrato de transporte, así como de representación de las mercancías transportadas durante su ejecución se sustituye en todo o parte por uno o varios mensajes de datos, o intercambios electrónicos de datos (EDI)", Alba Fernández, Manuel; García Mandaloniz, Marta; Rodríguez de las Heras Ballell, Teresa, "Electronificación de Instrumentos de Transporte Aéreo de Mercancías: El Proyecto E-Freight”, Derecho de los Negocios (Madrid), 2006, N¹84, p. 24.

${ }^{16}$ Sobre el régimen jurídico de las anotaciones en cuenta en el Derecho chileno, vid. CABALLERo Germain, Guillermo, La custodia en el mercado de valores. De los títulos de crédito a los valores anotados en cuenta, Thomson Reuters, Santiago, 2016.

${ }^{17}$ Recalde Castells, cit. (n. 14), p. 575. Este autor distingue entre la desmaterialización de los valores mobiliarios, la cual se realiza mediante anotaciones en cuenta; y la desmaterialización de los instrumentos de transporte. En cuanto a la desmaterialización de los instrumentos del transporte según esta doctrina se debe hacer hincapié en que el fenómeno de la desmaterialización adquiere rasgos distintivos en este tipo de documentos. Esto derivado de que no todos ellos son títulos-valor negociables, ya que sólo se satisface esta 'función representativa' si el derecho a la restitución de las mercancías se incorpora en el documento, es decir, si no se puede reclamar del transportista la entrega de las mercancías sin la presentación del documento en el lugar de destino. El autor señala que las funciones tradicionales de prueba de la recepción, de las características de las mercancías y del contrato son cumplidas por los documentos del transporte, sean éstos negociables o no, a lo cual agrega que se entienden superados
} 
manifestaciones del comercio como es por ejemplo la posibilidad de emitir electrónicamente la factura.

Este proceso, que originalmente fue conocido como "la representación virtual de los derechos contenidos en títulos valores", actualmente se reconoce como "desincorporación" o "desmaterialización", y aunque para nosotros ambas expresiones se enmarquen dentro de la denominada electronificación de los títulos valores, no podemos soslayar que para la doctrina especializada, ${ }^{18}$ existe una diferencia fundamental entre estas dos situaciones, cual es el hecho que en la primera, desincorporación, el derecho se desmaterializa o se desincorpora del título sustituyéndose por una serie de anotaciones contables a las que se les aplica un régimen jurídico propio, mientras que en la segunda, desmaterialización, lo que se desmaterializa es el título y no el derecho, que se mantiene incorporado en aquél a través del soporte electrónico que lo contiene, debiéndose aplicar a estos el régimen propio de los títulos valores con las modificaciones propias de los avances tecnológicos.

De tal forma, si siguiéramos esta tesis, se explicaría que el régimen de la desmaterialización por desincorporación sea propio de los títulos valores emitidos en masa (acciones de una sociedad anónima por ejemplo), mientras que la desmaterialización del soporte documental, surge a consecuencia del desarrollo del comercio en internet, aplicable principalmente a los títulos valores, susceptibles de ser usados como medio de pago.

Lo anterior para nosotros funciona como esquema, ya que permite distinguir claramente las dos situaciones que podrían darse; por un lado la

todos los obstáculos para cambiar el soporte tradicional de papel por uno electrónico, sin embargo, las mayores dificultades parecen presentarse en el caso de los documentos del transporte negociables.

${ }^{18}$ Rico CARRILlo, Mariliana, "El Tratamiento Electrónico de los Títulos Valores", Revista de Contratación Electrónica (RCE - Cádiz), 2002, № 24, pp. 24-25. La autora destaca que se ha hablado indistintamente de "electronificación", "desmaterialización” y "desincorporación”, señalando además que los dos últimos conceptos han sido tratados como sinónimos. Sin embargo, ella precisa estas acepciones y, a pesar de su uso, estima que no son del todo equivalentes. La desmaterialización entraña una sustitución del tradicional papel como soporte de los derechos incorporados en los títulos valores. A juicio de la autora, este concepto puede estudiarse desde dos aspectos: la desmaterialización de los derechos incorporados en el título; y la desmaterialización del soporte físico que contiene el título mediante un cambio en la naturaleza del soporte documental. Para esta doctrina, la importancia de la distinción entre ambos tipos de desmaterialización estriba en que existen consecuencias jurídicas distintas entre ambos tipos de desmaterialización. En el primer caso (desincorporación) existe una gran modificación a la estructura de todo título valor ya que el soporte documental es suprimido totalmente, y en su lugar existen anotaciones contables a las cuales deberá aplicárseles un régimen jurídico propio, distinto al aplicable a los títulos-valores tradicionales, existe una real "desnaturalización" de su esencia. En cambio, en el segundo caso lo que se desmaterializa es el título y no el derecho que se mantiene incorporado en aquél a través del soporte electrónico que lo contiene. En esta segunda situación sí es posible aplicar la regulación propia de los títulos-valores, naturalmente que con las modificaciones propias de este nuevo entorno electrónico. 
aplicación de un sistema de registros para la transferencia de la titularidad de los derechos y, por otra parte, la circulación propiamente tal de un documento electrónico que lleve incorporado en sí un derecho. Sin embargo, a pesar de ser una adecuada sistematización, discrepamos a nivel terminológico, precisamente en lo relativo a "desmaterializar un derecho", ya que, como hemos señalado anteriormente, los derechos son siempre incorporales, inmateriales (art. 565 CC: "Los bienes consisten en cosas corporales o incorporales......Incorporales las que consisten en meros derechos, como los créditos, y las servidumbres activas"), por lo tanto, no es posible desmaterializar algo que no está compuesto por materia, entendida ésta en la forma en que es definida en su sentido natural y obvio (para la RAE, materia es: "Realidad espacial y perceptible por los sentidos, que, con la energía, constituye el mundo fisico"), es por ello que, a nuestro juicio, ambos conceptos se encuadran dentro del fenómeno denominado electronificación de los títulos valores, debido a que la informática ha llevado a una sustitución del soporte de papel por uno electrónico e intangible.

Independiente de la denominación del fenómeno descrito, fundamental para nosotros es destacar que este proceso mediante el cual se incorpora la tecnología a los títulos valores, no es más que aplicar a su respecto la evolución de la teoría de los títulos de crédito. En efecto, si bien en un principio los derechos (que como hemos dicho son siempre incorporales), fueron materializados o incorporados a un soporte material para poder aplicarles el régimen de las cosas muebles, ahora son objeto de la materialización electrónica de sus tradicionales, es decir cambian el soporte en que se materializan. Mediante el empleo de medios electrónicos, es posible hacer anotaciones que sirven para crear y probar la existencia de un derecho a favor de cierto titular y mediante otra anotación es posible registrar la transferencia del derecho hacia otra persona.

El reemplazo de la emisión de un título valor por anotaciones en cuenta, es posible gracias a la reutilización del concepto de anotación contable desde el punto de vista jurídico. ${ }^{19}$ En efecto, si bien en un comienzo la anotación en cuenta se limitaba a acreditar el pago mediante la entrega de dinero o un

${ }^{19}$ La sustitución del soporte papel de los títulos por anotaciones contables hechas mediante el empleo de medios electrónicos, se ha recogido en diversos Ordenamientos Jurídicos, tanto respecto de los títulos masivamente emitidos (acciones de una sociedad anónima), como de los títulos representativos de dinero o efectos de comercio. En el Derecho chileno, el primer acercamiento hacia la representación electrónica de los títulos valores se advierte en la Ley $\mathrm{N}^{\circ} 18.876$, de 21 de diciembre de 1989, relativa a la constitución y operaciones de entidades privadas de depósito y custodia de valores, que permite realizar operaciones de transferencia o de constitución de derechos reales sobre los títulos entregados en depósito y custodia, mediante una comunicación escrita o por medios electrónicos. SANDOVAL LóPEZ, cit. (n. 14), pp. 81-84. 
documento representativo de dinero, hoy en día esta anotación contable tiene un valor propio, autónomo, que no sólo se limita a registrar la entrega de una cosa o de un título a cambio del pago en dinero de una operación determinada, sino que basta el mero asiento contable para que se produzcan los efectos de los títulos traslaticios de dominio, o sea, la anotación en cuenta se convierte en el registro constitutivo del derecho de que se trate asumiendo la función que desempeña el soporte documental del título de crédito, de tal manera que basta la sola anotación en el registro electrónico de quien emite el documento prescindiendo del documento papel.

De tal manera, el soporte electrónico permite que se puedan registrar los elementos característicos de un derecho como son: el titular, el contenido, la extensión y modalidades del derecho, pudiendo incluirse además una descripción técnica de la operación de adquisición y traspaso de ese derecho. Es decir, y analizándolo desde la estructura del título valor, la obligación de contenido obligacional se conformará por una anotación en cuenta, sólo que en este caso realizada por medios electrónicos o telemáticos.

La instrumentación técnica del sistema de derechos electronificados que ahora ya no se incorporan al papel ni a ningún otro soporte físico determinará la regulación jurídica del nuevo fenómeno. En efecto, su forma de creación y de traspaso será diferente a las de los títulos tradicionales, y por ello el ordenamiento así lo reconoce tal como ocurre en el art. $9^{\circ}$ de la Ley 19.983.

Mas, esta idea, que en principio nos llevaría a distinguir el régimen aplicable a los documentos electrónicos del régimen tradicional de los títulos valores, sin embargo, como hemos dicho, es la misma construcción conceptual, solo que opera ante una nueva realidad material, por cuanto, aunque nos encontramos ante una forma distinta jurídica de cómo circulan los bienes y créditos, la esencia de los valores anotados telemáticamente está formada, al igual que los títulos tradicionales, por derechos de contenido patrimonial.

La teoría de los títulos valores, entendida de esta forma y concordada con el principio de la equivalencia funcional según veremos, es lo que ha permitido una evolución de la regulación a la par de las nuevas tecnologías.

\section{EL PRINCIPIO DE EQUIVALENCIA FUNCIONAL COMO ELEMENTO BASE DE LA ELECTRONIFICACIÓN}

\subsection{Los principios del Comercio Electrónico (CE) en general}

Sin perjuicio del reconocimiento expreso de un régimen propio del $\mathrm{CE}$ en distintos textos de derecho positivo, como por ejemplo la Ley Modelo 
sobre Comercio Electrónico de UNCITRAL ${ }^{20}$ (LMUCE) ${ }^{21}$ la Convención de las Naciones Unidas sobre la Utilización de las Comunicaciones Electrónicas en los Contratos Internacionales (CNUUCECI), ${ }^{22}$ o la LFE en el caso del Ordenamiento chileno, tradicionalmente la disciplina del Derecho del CE se ha ido desarrollando en torno a grandes principios jurídicos que lo rigen. ${ }^{23}$

En efecto, los rasgos definitorios y propios del comercio electrónico dan la pauta para admitir que el Derecho que lo regule ha de estar sustentado en ciertos principios orientadores que recojan su especialidad, sin perjuicio de que al tratarse ni más ni menos que de una especie particular de comercio, haga suyos también los principios que sirven de sustento al derecho mercantil en general. ${ }^{24}$

Estas directrices, que nacieron desde una perspectiva eminentemente teórica, fruto de la disponibilidad del acceso a internet y de los pocos textos jurídicos que aludían al tema del comercio electrónico, no fueron objeto de consagración legislativa expresa en un comienzo, ya que según ha sido descrito, "como buenos principios que son, los mismos formalmente no son objeto de consagración legislativa ni aparecen mencionados en ninguna parte...". 25

No obstante, ello no significa que los legisladores no se hayan dejado influenciar por tales principios al momento de legislar, sino que al contrario, en algunos ordenamientos como el chileno, se les reconoce expresamente, no sólo en materia de comercio electrónico $\left(\mathrm{LFE}\right.$, art. $\left.1^{\circ}\right),{ }^{26}$ sino que en otras materias, como por ejemplo, la tramitación electrónica ante nuestros tribunales (art. $2^{\circ}$ Ley 20.886). ${ }^{27}$

\footnotetext{
${ }^{20}$ Comisión de las Naciones Unidas para el Derecho Mercantil Internacional, www.uncitral.org.

${ }^{21}$ La Ley Modelo sobre Comercio Electrónico de UNCITRAL (LMUCE), aprobada por resolución 51/162 de la Asamblea General de Naciones Unidas el 16 de diciembre de 1996.

${ }^{22}$ La Convención de las Naciones Unidas sobre la Utilización de las Comunicaciones Electrónicas en los Contratos Internacionales (CNUUCECI), aprobada por resolución 60/21 de la Asamblea General de Naciones Unidas el 23 de noviembre de 2005.

${ }^{23}$ Principios enunciados por Illescas Ortiz, Rafael, "Los Principios de Contratación Electrónica Revisitados", en Madrid Parra, A.; Guerrero Lebrón, M. (coords.), Derecho Patrimonial y Tecnología, Marcial Pons, Madrid, 2007, pp. 21-38, y también en Illescas Ortiz, Rafael, Derecho de la Contratación Electrónica, Civitas Ediciones, Madrid, 2009, 2ª ed., pp. 33-62.

${ }^{24}$ Sandoval López, Ricardo, Derecho del comercio electrónico, análisis de la ley 19.799, sobre documentos electrónicos, firma electrónica y servicios de certificación de dicha firma, Editorial Jurídica de Chile, Santiago, 2003, $1^{\text {a }}$ Ed., p. 42.

${ }^{25}$ Illescas Ortiz, Los principios ... cit. (n. 23), p. 25.

${ }^{26}$ Art. $1^{\circ}$ incs. $2^{\circ}$ y $3^{\circ}$, LFE: "Las actividades reguladas por esta ley se someterán a los principios de libertad de prestación de servicios, libre competencia, neutralidad tecnológica, compatibilidad internacional y equivalencia del soporte electrónico al soporte de papel.

Toda interpretación de los preceptos de esta ley deberá guardar armonía con los principios señalados". ${ }^{27}$ Art. $2^{\circ}$, Ley 20.886: "Principios. La tramitación de las causas regidas por la presente ley se sujetará a los siguientes principios generales: a) Principio de equivalencia funcional del soporte electrónico. Los
} 
Con todo, y según ha dicho la doctrina ${ }^{28}$ los principios universales en que debiera inspirarse el derecho del comercio electrónico, y por ende, sus diversas manifestaciones son: la equivalencia funcional de los actos electrónicos respecto de los manuales o autógrafos, la neutralidad tecnológica de las disposiciones reguladoras del comercio electrónico, la inalteración del derecho preexistente de obligaciones y contratos, la exigencia de muy buena fe y finalmente, la reiteración de la libertad de pacto y su ejercicio en el nuevo contexto del comercio electrónico.

\subsection{La equivalencia funcional. Delimitación conceptual}

\section{En el seno de la UNCITRAL, al elaborar la LMUCE, se tuvo en cuenta}

actos jurisdiccionales y demás actos procesales suscritos por medio de firma electrónica serán válidos y producirán los mismos efectos que si se hubieren llevado a cabo en soporte papel...".

b) Principio de fidelidad. Todas las actuaciones del proceso se registrarán y conservarán íntegramente y en orden sucesivo en la carpeta electrónica, la que garantizará su fidelidad, preservación y la reproducción de su contenido.

c) Principio de publicidad. Los actos de los tribunales son públicos y, en consecuencia, los sistemas informáticos que se utilicen para el registro de los procedimientos judiciales deberán garantizar el pleno acceso de todas las personas a la carpeta electrónica en condiciones de igualdad, salvo las excepciones establecidas por la ley.

No obstante lo anterior, las demandas, las presentaciones relativas a medidas cautelares, incluso aquellas solicitadas en carácter prejudicial, y a otras materias cuya eficacia requiera de reserva serán accesibles únicamente al solicitante mientras no se haya notificado la resolución recaída en ellas.

Se prohíbe el tratamiento masivo de los datos personales contenidos en el sistema de tramitación electrónica del Poder Judicial, sin su autorización previa.

La infracción cometida por entes públicos y privados a lo dispuesto en este inciso será sancionada conforme a la Ley $N^{\circ} 19.628$.

La Corte Suprema regulará mediante auto acordado la búsqueda de causas en el sistema de tramitación electrónica del Poder Judicial.

d) Principio de buena fe. Las partes, sus apoderados y todos quienes intervengan en el proceso conforme al sistema informático de tramitación deberán actuar de buena fe.

El juez, de oficio o a petición de parte, deberá prevenir, corregir y sancionar, según corresponda, toda acción u omisión que importe un fraude o abuso procesal, contravención de actos propios o cualquiera otra conducta ilícita, dilatoria o de cualquier otro modo contraria a la buena fe.

e) Principio de actualización de los sistemas informáticos. Los sistemas informáticos de tramitación del Poder Judicial deberán ser actualizados a través de la Corporación Administrativa del Poder Judicial con el objeto de permitir su correcto funcionamiento y la más fluida y expedita interconexión e interoperabilidad entre sí y con otras instituciones públicas.

f) Principio de cooperación. Los auxiliares de la administración de justicia, las instituciones públicas y el Poder Judicial deberán cooperar entre sí en la utilización de medios electrónicos con el objeto de garantizar la interconexión e interoperabilidad de los sistemas informáticos y, en particular, el reconocimiento mutuo de los documentos electrónicos y de los medios de identificación y autentificación respectivos.

Para ello, las instituciones públicas y los tribunales propenderán a la celebración de convenios de cooperación.

${ }^{28}$ Illescas Ortiz, Derecho ... cit. (n. 23), p. 37. 
el principio de la equivalencia funcional como principio básico del derecho de la contratación electrónica. ${ }^{29} \mathrm{La}$ idea sobre la que subyace el postulado se construye a partir de una premisa, cual es que los elementos estructurales de todo documento escrito son, de un lado, su información o contenido literal y de otro, el soporte idóneo donde tal información se plasma, registra o incorpora. Con la vinculación de ambos elementos, el documento escrito se encuentra capacitado para cumplir con sus funciones correspondientes.

La información o contenido literal del documento escrito se incorpora en el elemento estructural del soporte, luego, las funciones con las cuales debe cumplir un determinado documento se desprenden de su respectiva información general que permite determinar su clase o naturaleza, de tal forma que cualquier documento deberá cumplir con la mismas funciones cualquiera que sea su soporte, operando de tal modo el principio de equivalencia funcional, y cuyo significado puede formularse de la manera que venimos expresando: la función jurídica que en toda su extensión cumple la instrumentación escrita y autógrafa (o eventualmente su expresión oral), respecto de cualquier acto jurídico, la que cumple igualmente su instrumentación electrónica a través de un mensaje de datos, con independencia del contenido, dimensión, alcance y finalidad del acto instrumentado de esta forma.

Luego, en virtud de este principio, los documentos electrónicos cumplen las mismas funciones que los documentos con soporte material de papel, por lo que no se puede negar efecto jurídico, validez ni obligatoriedad a los documentos, a las firmas, ${ }^{30}$ ni a los actos y contratos electrónicos en general, por el solo hecho de que se encuentren en formato electrónico. ${ }^{31}$

\footnotetext{
${ }^{29}$ Sin perjuicio de ello, MAdRID PARRA aporta que en el $25^{\circ}$ período de sesiones del Grupo de Trabajo sobre Intercambio Electrónico de datos de UNCITRAL, que tuvo lugar entre el 4 al 15 de enero de 1993, en el que se examinaron las distintas materias que podrían ser objeto de futuras reglas uniformes relativas al EDI (Electronic Data Interchange), el grupo de trabajo ya trabajaba la idea de un equivalente funcional de escrito como requisito de forma al tratamiento uniforme de EDI (MADRID PARRA, Agustín, "EDI (Electronic Data Interchange): Estado de la Cuestión en Uncitral", Revista de derecho mercantil (Madrid) 1993, No 207, p. 131.

${ }^{30}$ Lo que rige tanto para firma electrónica simple o firma electrónica avanzada, no obstante sea necesario destacar el hecho que la firma simple sólo asegura la autenticación, en tanto que la avanzada asegura la autenticación, integridad, confidencialidad y no repudio, siendo entonces más segura. CRUZ RIVERO, Diego, Eficacia formal y probatoria de la firma electrónica, Marcial Pons, Madrid, 2006, pp. 38 y ss.

${ }^{31}$ SANDOVAL, indica que la equivalencia funcional significa que se confiere eficacia jurídica a todo acto o contrato, transacción u operación, sea que se haya convenido entre particulares o en el ámbito del sector público, celebrado por medios electrónicos, esté o no certificada y en el caso de estarlo, que el prestador de servicios de certificación esté o no acreditado, salvo los casos que expresamente se han exceptuado. Lo que importa entonces es reconocer que la función jurídica que cumple el documento escrito en papel y con firma manuscrita, en relación con todo acto o contrato, la satisface igualmente el documento
} 
La equivalencia funcional, por lo tanto, implica aplicar a los mensajes de datos electrónicos una pauta de no discriminación respecto de las declaraciones de voluntad o ciencia, verbal o gestualmente efectuadas por el mismo sujeto y con los mismos fines. ${ }^{32}$

A partir de lo descrito, se ha definido a la equivalencia funcional ${ }^{33}$ como el principio básico de todo el sistema de reglas, legales y contractuales, que permiten que el comercio electrónico en particular y la contratación electrónica en general produzcan en derecho los efectos apetecidos por quienes participan en él a través de las diversas caracterizaciones que el intercambio de bienes y servicios permite y requiere.

De la aplicación del referido principio se desprende el éxito o fracaso de las nuevas formas de contratación telemáticas, por cuanto, en su virtud, se atribuye a los datos informáticos, independientemente de que se envíen como mensajes de datos o que se almacenen, el mismo valor jurídico que el de los datos estampados en un documento con soporte material de papel. ${ }^{34}$

De lo anterior podemos colegir que el principio de la equivalencia funcional se entrelaza o relaciona de manera muy cercana con otro principio del $\mathrm{CE}$, la no discriminación, ${ }^{35}$ por cuanto se debe atribuir igual valor a las declaraciones hechas por medios electrónicos, frente a declaraciones hechas por otros medios como el oral o el escrito. ${ }^{36}$

electrónico, con independencia del contenido y de la finalidad perseguida por el acto documentado. Por lo que, los documentos electrónicos no son discriminados frente a los instrumentos escritos en papel o a las declaraciones de voluntad hechas en forma oral o consensuales. SANDOval, cit. (n. 24), p. 128.

32 Illescas Ortiz, Rafael, "La Equivalencia Funcional como Principio Básico del Derecho de la Contratación Electrónica", Revista Aranzadi de Derecho y Nuevas Tecnologías (Thompson Aranzadi - Navarra), 2003, $\mathrm{N}^{\circ}$ 1, p. 21. Comparte esta misma idea Ricardo Sandoval señalando que "no puede haber discriminación respecto a las declaraciones efectuadas en un medio electrónico, toda vez que el soporte que contiene la declaración de voluntad puede ser escrito o electrónico". SANDOVAL López, Ricardo, "Principios que informan el derecho del comercio electrónico", Revista de Derecho Universidad de Concepción, 2001, № 210, p. 171.

${ }^{33}$ ILlESCAS, cit. (n. 32), p.19. Este autor afirma que en el caso del Ordenamiento español la primera consagración positiva de este principio se encuentra en el art 3.1 del Real Decreto-Ley 14/1999, de 17 de septiembre de 1999 (RCL 1999, 2379), sobre firma electrónica (BOE. № 224 de 18 de septiembre de 1999). En el caso chileno esto también ocurrió en la llamada Ley de firma electrónica, Ley 19.799, que en su art. $1^{\circ}$ inciso $2^{\circ}$ habla directamente del principio de equivalencia del soporte electrónico al soporte papel.

${ }^{34}$ SAndoval, cit. (n. 14), p. 91.

${ }^{35}$ Esto nos queda muy claro al estudiar lo que dicen los autores en torno a ambos principios. Sandoval e Illescas recurren a la idea de la no discriminación para poder explicar el principio de la equivalencia funcional.

${ }^{36}$ Para algunos, reconocido es que se haya discutido, desde una perspectiva exclusivamente dogmática, si estos dos principios en realidad son diferentes o se trata de manifestaciones de uno solo. Queda 
Para que el principio de equivalencia funcional produzca todos sus efectos se requiere: i) la existencia de dos o más documentos de igual clase o naturaleza; ii) la existencia de dos o más documentos que posean la misma información general básica y que estén destinados a cumplir las mismas funciones básicas; $y$, iii) que concurra la de circunstancia de que, al menos uno de estos documentos, utilice como elemento estructural un soporte de carácter electrónico. ${ }^{37}$

Cumplidos estos requisitos tendrá lugar la equivalencia funcional, en cuya virtud no se podrá discriminar o negar efectos jurídicos, validez o fuerza obligatoria al contenido literal plasmado en un documento que utilice como elemento estructural un soporte electrónico. ${ }^{38}$

En cuanto a las funciones de este principio, y analizado a propósito de la LMUCE, se destaca el hecho de que en esta Ley modelo no entró a regular los efectos jurídicos sustantivos de los mensajes de datos en cada uno de los casos concretos en los cuales fueran utilizados, sino que la opción fue la de identificar algunos elementos especialmente relevantes en el tráfico mercantil cuyo soporte solía ser el papel, y de esta forma poder analizar las funciones que cumplen y determinar qué requisitos había de reunir la misma información constando en un soporte electrónico para que las funciones desarrolladas sean las mismas y, en consecuencia, también lo fueran los efectos jurídicos, ${ }^{39}$ de ahí entonces la importancia para nuestro análisis, por cuanto lo que se diga en abstracto sobre un

planteada la duda, pero lo que no se puede soslayar es el hecho que sólo existe una regla general de equivalencia con dos dimensiones: una positiva, la propia equivalencia funcional, y otra negativa, la no discriminación. ILLESCAS, cit. (n. 32), p. 19.

${ }^{37} \mathrm{La} \mathrm{LFE} \mathrm{(art.} 3^{\circ}$ inc. $1^{\circ}$ ) agregó como requisito extra que el documento que utilice como elemento estructural un soporte de carácter electrónico debe estar suscrito por medio de una firma electrónica, lo que entendemos no es más que una referencia expresa al objeto que venía a regular, documento electrónico y firma electrónica.

${ }^{38}$ Sin perjuicio de lo anterior, la doctrina extranjera ha establecido, como presupuestos que deben concurrir para que se constituya este principio de la equivalencia funcional: existencia de acuerdo convencional que otorgue validez al documento electrónico negociable; existencia de un sistema de información seguro por parte del iniciador del mensaje y de sus sucesivos tenedores que tenga como finalidad garantizar la seguridad en la emisión, conservación y transferencia del archivo, identidad de la persona que posee el control del mensaje y la emisión de un ejemplar único, identificable e inalterable. Rico CARRILlO, cit. (n. 18), p. 32. Para la doctrina chilena se han señalado como requisitos: que existan dos o más documentos que se pretendan equivalentes; que se trate de documentos que posean la misma información general básica; que se trate de documentos de igual clase o naturaleza; que los documentos estén destinados a cumplir con las mismas funciones básicas que les sean propias; que al menos uno de ellos utilice como elemento estructural un soporte de carácter electrónico. BARROILHET ACEVEDO, Claudio; Basso Cerda, Osvaldo, Conocimiento de Embarque Electrónico, Librotecnia, Santiago, 2005, p. 135.

${ }_{39}$ Madrid Parra, Agustín, "El Convenio de Naciones Unidas sobre Contratación Electrónica”, en Madrid Parra, A.; Guerrero Lebrón, M. (coords.), Derecho Patrimonial y Tecnología, Marcial Pons, Madrid, 2007, p. 66. 
documento electrónico en general, resulta perfectamente aplicable, por ejemplo, a la factura electrónica en concreto.

\subsection{La equivalencia funcional en la $L F E$}

En el Derecho chileno, la LFE, siguiendo la tendencia internacional sobre la materia, pretendió establecer un marco regulatorio que otorgara a los actos y contratos celebrados por medios electrónicos el mismo reconocimiento y protección ante el derecho que reciben los celebrados de manera convencional.

Sin perjuicio de lo anterior, debemos tener presente que esta normativa se dictó con el sólo objeto de regular a la firma electrónica y a las entidades certificadoras. La insuficiencia normativa, propia de nuestro Ordenamiento, ha convertido en la práctica a la LFE como el estatuto jurídico regulador del comercio electrónico en el sistema jurídico chileno, abarcando en forma omnicomprensiva materias que exceden su natural campo de aplicación, como las más distintas aristas del comercio electrónico, la protección de los consumidores o aspectos procesales.

En el art $1^{\circ}{ }^{40}$ fija el ámbito de aplicación de la ley, estableciendo en su inc. $2^{\circ}$ los principios orientadores que la inspiran y consagrando la "equivalencia del soporte electrónico al papel", que es como llama a la equivalencia funcional, en el cual se fundamentan determinadas disposiciones.

Entre las manifestaciones directas del principio de la equivalencia funcional, se encuentra el art $3^{\circ}$ inc. $1^{\mathrm{o}} .^{41}$ Conforme a esta disposición, sólo un documento electrónico firmado electrónicamente será funcionalmente equivalente a un

\footnotetext{
${ }^{40}$ Artículo $1^{\circ}$. "La presente ley regula los documentos electrónicos y sus efectos legales, la utilización en ellos de firma electrónica, la prestación de servicios de certificación de estas firmas y el procedimiento de acreditación al que podrán sujetarse los prestadores de dicho servicio de certificación, con el objeto de garantizar la seguridad en su uso. Las actividades reguladas por esta ley se someterán a los principios de libertad de prestación de servicios, libre competencia, neutralidad tecnológica, compatibilidad internacional y equivalencia del soporte electrónico al soporte de papel. Toda interpretación de los preceptos de esta ley deberá guardar armonía con los principios señalados".

${ }^{41}$ Artículo $3^{\circ}$ Ley 19.799: "Los actos y contratos otorgados o celebrados por personas naturales o jurídicas, suscritos por medio de firma electrónica, serán válidos de la misma manera y producirán los mismos efectos que los celebrados por escrito y en soporte de papel. Dichos actos y contratos se reputarán como escritos, en los casos en que la ley exija que los mismos consten de ese modo, y en todos aquellos casos en que la ley prevea consecuencias juridicas cuando constan igualmente por escrito. Lo dispuesto en el inciso anterior no será aplicable a los actos o contratos otorgados o celebrados en los casos siguientes: a) aquellos en que la ley exige una solemnidad que no sea susceptible de cumplirse mediante documento electrónico; b) aquellos en que la ley requiera la concurrencia personal de alguna de las partes, y c) aquellos relativos al derecho de familia. La firma electrónica, cualquiera sea su naturaleza, se mirará como firma manuscrita para todos los efectos legales, sin perjuicio de lo establecido en los artículos siguientes".
} 
documento en soporte papel y, por lo tanto, será válido igual que éste y producirá sus mismos efectos, a contrario sensu, si no estuviere firmado no operaría la equivalencia funcional. Según nuestra doctrina nacional ${ }^{42}$ la Ley chilena no pretende consagrar la equivalencia funcional en términos absolutos, sino que hace una suerte de homologación, en cuanto a los efectos de la firma electrónica respecto de la firma ológrafa en aquellas normas de nuestro ordenamiento jurídico que se refiera a ellas.

Como ya hemos dado por establecido la equivalencia funcional implica aplicar a los mensajes de datos electrónicos un régimen de no discriminación respecto de las declaraciones de voluntad, verbal, oral o gestualmente efectuadas por el mismo sujeto y con los mismos fines u objetivos. Los efectos jurídicos pretendidos por el emisor de la declaración deben producirse y reconocerse por el Ordenamiento jurídico con independencia del soporte escrito o electrónico en que la declaración conste. ${ }^{43}$

Sin perjuicio de la importancia que adquiere para el Derecho la consagración de este principio, debemos advertir que su admisión trae aparejados ciertos problemas, que han de ser resueltos por los distintos sistemas jurídicos. Así por ejemplo, se advertía por nuestra doctrina ${ }^{44}$ que, aceptado que sea el principio y como consecuencia del mismo, habría que admitir a los documentos electrónicos como medios de prueba y asimismo darle el mérito probatorio que corresponda, estableciendo en cada caso los requisitos e incorporando los medio tecnológicos suficientes para ello.

\section{LA RECEPCIÓN DE LA FACTURA ELECTRÓNICA EN LA LEY 19.983}

\subsection{Aspectos generales}

Tal como hemos indicado ${ }^{45}$ la Ley. 20.727, por medio de una modificación

\footnotetext{
42 Barroilhet Acevedo y Basso Cerda, cit. (n. 38), pp. 176-177.

${ }^{43}$ ILlescas, cit. (n. 32), p. 21.

${ }^{44}$ En tal sentido, Sandoval, cit. (n. 32), p. 171. En efecto la Ley 19.799, establece normas de orden procesal en los artículos, $4^{\circ}, 5^{\circ}, 6^{\circ}$ y $7^{\circ}$. Lo anterior sin perjuicio que la irrupción de documentos electrónicos dio origen a modificaciones como el art. 348 bis del Código de Procedimiento Civil (Ley 20.217 de 12 de noviembre de 2007), o las incorporadas por la ya referida Ley 20.886 sobre tramitación electrónica. Sobre esta materia vid. Contreras Strauch, Osvaldo, "Aspectos probatorios de la contratación electrónica", en De la Maza G., I. (coord.), Derecho y Tecnologías de la Información, Universidad Diego Portales, Fundación Fernando Fueyo Laneri, Santiago, 2002.

${ }^{45}$ Vid. Supra, $\mathrm{N}^{\circ} 1$ de este trabajo.
} 
al DL 825, vino a establecer la obligatoriedad de emitir la factura en forma electrónica. Como sabemos, no existe en nuestro ordenamiento una regulación especial para este título, sin perjuicio de las disposiciones consagradas a su respecto en el Código de Comercio (CCo), el Código Tributario (CT), y muy especialmente en la Ley 19.983, que por medio de sus normas consagra la emisión, cesión y construcción del mérito ejecutivo de la copia cedible de la factura (creada a tal efecto por Ley), conforme la ritualidad y los procedimientos establecidos en ella. ${ }^{46}$

Aunque la posibilidad cierta de emitir una factura electrónica ya fuera reconocida por nuestro Derecho, en virtud de las disposiciones de la LFE, y la normativa que al respecto dictara el SII, ${ }^{47}$ para nosotros no es sino hasta dictarse la Ley 19.983 que tal posibilidad comienza a consolidarse en el tráfico mercantil.

En efecto, y según lo dispone expresamente el art. $9^{\circ}$ del referido estatuto:48 "Las normas de la presente ley serán igualmente aplicables en caso que la factura sea un documento electrónico emitido de conformidad a la ley por un contribuyente autorizado por el Servicio de Impuestos Internos. En tal caso, el recibo de todo o parte del precio o remuneración deberá ser suscrito por el emisor con su firma electrónica, y la recepción de las mercaderías o servicios que consten en la factura podrá verificarse con el acuse de recibo electrónico del receptor. No obstante, si se ha utilizado guía de despacho, la recepción de las mercaderías podrá constar en ella, por escrito, de conformidad con lo establecido en esta ley. Tratándose de receptores de mercaderías o servicios que no sean contribuyentes obligados a emitir documentos tributarios electrónicos, el acuse de recibo debe constar en la representación impresa del documento que se trate. Asimismo, habiendo transcurrido el plazo establecido en el inciso cuarto del artículo $4^{\circ}$, sin haber sido reclamada la factura conforme al artículo $3^{\circ}$, la factura electrónica o la guía de despacho electrónica, con su correspondiente factura, será cedible y podrá contar con mérito ejecutivo, entendiéndose recibidas las mercaderías entregadas o el servicio prestado, sin necesidad que el recibo sea otorgado en las formas indicadas en el presente inciso.

\footnotetext{
${ }^{46}$ La factura como título de crédito ya ha sido abordada por nosotros en EsCOBAR, Maximiliano; HoYUELA, Camila, "La factura. Un análisis sustantivo del título al tenor de la ley 19.983 y sus modificaciones", Revista de Derecho Universidad de Concepción, 2016, No 240 (Jul-Dic), pp.7-40.

${ }^{47}$ En concreto nos referimos a la ya citada (n. 7), Resolución Exenta № 45 SII, por la que estableció normas y procedimientos de operación respecto de los documentos tributarios electrónicos

${ }^{48}$ Redacción después de haber sido modificado sucesivamente por la leyes 20.219 (Art. 5 D.O. 03.10.2007), y 20.956 (Art. $4 \mathrm{~N}^{\circ} 4$, D.O. 26.10.2016).
} 
Sin perjuicio de lo señalado en el artículo $7^{\circ}$, cesión del crédito expresado en estas facturas solamente podrá efectuarse mediante medios electrónicos y se pondrá en conocimiento del obligado al pago de ellas, mediante su anotación en un registro público electrónico de transferencias de créditos contenidos en facturas electrónicas que llevará el Servicio de Impuestos Internos. Se entenderá que la transferencia ha sido puesta en conocimiento del deudor el día hábil siguiente a aquel en que ella aparezca anotada en el registro señalado. El Servicio de Impuestos Internos podrá encargar a terceros la administración del registro.

El reglamento ${ }^{49}$ para la ejecución de este artículo deberá ser dictado dentro del plazo de dos meses, contados desde la publicación de la presente ley”.

A partir del texto de la Ley, el análisis que a nuestro juicio debe tener lugar es si acaso, las aptitudes probatorias, constitutivas y dispositivas, que de acuerdo a las normas de los arts. $1^{\circ}, 2^{\circ}, 3^{\circ}, 4^{\circ}, 5^{\circ}, 7^{\circ}$, del referido estatuto, han permitido configurar a la factura como título valor según nuestra doctrina ${ }^{50}$ y jurisprudencia, ${ }^{51}$ se cumplen de igual manera a propósito de la factura electrónica.

\subsection{La factura electrónica como equivalente funcional}

Definida en el art. $2^{\circ}$ del DS 93, como "facturas de venta, facturas de compra, facturas exentas y liquidaciones factura, generadas como un documento electrónico emitido y firmado por un contribuyente autorizado por el Servicio de Impuestos Internos", el primer desafío respecto de la factura electrónica radica en determinar si a su respecto se aplica la construcción propia de los título de crédito electrónicos, que en virtud del principio de equivalencia funcional permiten a éstos cumplir idénticas funciones que sus similares en formato tradicional.

\footnotetext{
${ }^{49}$ Decreto $\mathrm{N}^{\circ} 93$, de 13 de abril de 2005, del Ministerio de Hacienda.

${ }^{50}$ En tal sentido Prado Puga, Arturo, "Alcance jurídico de la factura como título de circulación mercantil”, Revista de Derecho P. Universidad Católica de Valparaíso, 2016, Vol. XLVI, p. 160.

${ }^{51}$ Corte Suprema, 7 de diciembre de 2010, "Hidromecánica y Estructuras Integrales con Óscar Azócar Larenas y Compañía Limitada", Rol No 6469-2009; Corte Suprema, 7 de diciembre de 2010, "Sociedad de transporte Latino Kunstmann Limitada con Sociedad Frutos del País Frías y Quera Limitada", Rol 7217-2009; Corte Suprema, 29 de diciembre de 2010, "Morales Villegas, Hernán con Veterquímica Limitada", Rol 6470-2009; Corte Suprema, 27 de enero de 2011, "CFC Capital S.A. con Veolía Water System Chile Limitada", Rol 9139-2009; Corte Suprema, 21 de septiembre de 2011, "Interfactor con Sindelen", Rol 3239-2010; Corte Suprema, 1 de diciembre de 2011, "Chile Factoring S.A. con Fernando Mayer Construcciones S.A.”, Rol 3117-2011.
} 
Para nosotros no hay duda alguna en responder afirmativamente, y es que, como venimos exponiendo, la función del principio de la equivalencia funcional es permitir a un documento cumplir con los cometidos tradicionales de otro, independientemente de cuál sea su soporte. Luego su finalidad no es otra que equiparar definitivamente el valor jurídico de ambos instrumentos, el tradicional y el electrónico.

En efecto, y según se ha indicado, ${ }^{52}$ lo importante no es el soporte, sino la información, ya que cuando se requiere un 'documento', por lo general no se pretende tanto disponer de un concreto papel, sino de aquel instrumento que, con mayor fiabilidad puede ofrecer la información íntegra tal cual se generó.

La norma que recoge el principio de equivalencia funcional concentra su núcleo esencial en el requisito de la integridad de la información tal cual se generó, más allá de la materialidad del documento en que ésta conste, luego deben ser otros elementos, tales como la escrituración (literalidad) y la autenticación (titularidad de las declaraciones contenidas en el título), los instrumentos técnicos que garanticen al título electrónico cumplir idénticas funciones a su similar en papel.

En el caso de la factura electrónica, esta arquitectura técnica viene dada por la posibilidad de emitirla telemáticamente (lo que ya se permitió desde la referida Resolución Exenta $\mathrm{N}^{\circ} 45$ SII de 2003), y la garantía, prescrita en el citado art. 9 de la Ley 19.983, que sobre ella se podrá configurar el mérito ejecutivo (art. 5), y se podrá ceder el crédito allí contenido (arts. $4^{\circ}, 7^{\circ}, 8^{\circ}$ ), y así lo han reconocido nuestros tribunales. ${ }^{53}$ Con todo, y a pesar de que conceptualmente se trata de un mismo documento, regulado en una misma disposición, las distintas actuaciones necesarias para alcanzar estos propósitos: aceptación irrevocable; cesión del crédito consignado en una factura electrónica; y construcción del mérito ejecutivo, reciben distinto tratamiento normativo y jurisprudencial a su respecto.

\subsection{La aceptación irrevocable de la factura electrónica}

Regulado en el art. $3^{\circ}$ de la Ley 19.983 (en su nueva redacción a partir de

\footnotetext{
${ }^{52}$ Madrid PARRA, cit. (n. 39), p. 69.

53 "La factura electrónica es un documento digital legalmente válido como medio de respaldo de las operaciones comerciales entre contribuyentes y, por lo tanto, reemplaza a las facturas tradicionales de papel. La empresa que otorga la factura, el facturador electrónico, habilita al contribuyente tanto como emisor y como receptor de los documentos Tributarios Electrónicos, como en este caso, de la factura electrónica y su correspondiente certificación o traza de la recepción del servicio". Corte de Apelaciones de San Miguel, 21 de agosto de 2017, "Taciones (sic) y asesorías con Manufacturas Interamericanas", Rol 843-2017.
} 
la Ley 20.956) entendemos que sobre la materia se han producido algunas de las modificaciones más sustantivas de la regulación de la factura, especialmente en materia de caducidad, por cuanto según dispone el inciso final: "Serán inoponibles a los cesionarios de una factura irrevocablemente aceptada, las excepciones personales que hubieren podido oponerse a los cedentes de la misma, así como aquellas fundadas en la falta total o parcial de entrega de las mercaderías o de la prestación del servicio, sin perjuicio de las acciones civiles y penales que correspondan contra el emisor".

En efecto, antes, la falta de entrega de las mercaderías o la falta de prestación de los servicios, era una exigencia legal para que la factura se cediera en propiedad, ${ }^{54}$ pero además esta excepción constituía uno de los fundamentos consagrados en la Ley (art. $5^{\circ} \mathrm{d}$ antigua redacción), ${ }^{55}$ para la oposición del deudor al legitimado activo, en la gestión preparatoria de cobro de la factura. Como hemos referido expresamente, la Ley 20.956 modificó a la 19.983, en el sentido que ahora se reconoce a la falta de entrega de las mercaderías o la falta de prestación de los servicios en el art $3^{\circ}$, como argumento para que el deudor evite que la factura quede irrevocablemente aceptada, pero ha eliminado tal circunstancia como fundamento de oposición de la gestión preparatoria de cobro (art. $5 \mathrm{~d}$, redacción actual). ${ }^{56}$

Con todo, una importante modificación incorporada es aquella que se consagra en el art. $3^{\circ}$ inc. $2^{\circ}$, al señalar que: La factura también se tendrá por irrevocablemente aceptada cuando el deudor, dentro del plazo de ocho días señalado anteriormente, declare expresamente aceptarla, no pudiendo con posterioridad reclamar en contra de su contenido o de la falta total o parcial de entrega de las mercaderías o de la prestación del servicio”.

\footnotetext{
${ }^{54}$ Lo que se mantiene conforme aún lo establece el art. $4^{\circ}$ letra b).

${ }^{55}$ Art. $5^{\circ}$ Ley 19.983 (anterior a la Ley 20.956): La misma copia referida en el artículo anterior tendrá mérito ejecutivo para su cobro, si cumple los siguientes requisitos: d) Que, puesta en conocimiento del obligado a su pago mediante notificación judicial, aquél no alegare en el mismo acto, o dentro de tercero día, la falsificación material de la factura o guía o guías de despacho respectivas, o del recibo a que se refiere el literal precedente, o la falta de entrega de la mercadería o de la prestación del servicio, según el caso, o que, efectuada dicha alegación, ella fuera rechazada por resolución judicial;" (el destacado es nuestro).

${ }^{56}$ Art. $5^{\circ}$ Ley 19.983 (redacción actual): La misma copia referida en el artículo anterior tendrá mérito ejecutivo para su cobro, si cumple los siguientes requisitos: d) Que, puesta en conocimiento del obligado a su pago mediante notificación judicial, aquél no alegare en el mismo acto, o dentro de tercero día, la falsificación material de la factura o guía o guías de despacho respectivas, o del recibo a que se refiere el literal precedente, o que, efectuada dicha alegación, ella fuera rechazada por resolución judicial. La impugnación se tramitará como incidente y, en contra de la resolución que la deniegue, procederá el recurso de apelación en el solo efecto devolutivo".
} 
La aceptación irrevocable de la factura fija su contenido literal. La especial dedicación con que el legislador se ha ocupado de su tratamiento radica en el hecho que, si se quiere que la factura pueda transferirse a terceros y tener mérito ejecutivo, previamente se requiere en forma imprescindible que ella se encuentre irrevocablemente aceptada. Esta exigencia nos ha llevado a concluir que la declaración contenida en la factura no tiene el carácter de unilateral, por el contrario, resulta ser bilateral, revocable y, especialmente no vinculante, hasta que la aceptación se haya producido. ${ }^{57}$

El problema radica en determinar la forma en que se declara expresamente aceptar una factura, pues si ello ocurre, caducará respecto a quien haga esta declaración, la posibilidad de impugnar con posteridad, al menos de acuerdo lo prescriben las normas de la Ley 19.983, su contenido, o la falta total o parcial de entrega de las mercaderías o de la prestación del servicio.

En virtud del principio de la literalidad de los títulos valores, la declaración debe constar materialmente en el documento, lo cual pareciera no generar mayores problemas si se trata de una factura en soporte papel. Ahora bien, si la factura es electrónica, entendemos que la forma de aceptarla expresamente es mediante el acuse de recibo electrónico (sin perjuicio de lo dispuesto en el art. $9^{\circ}$ inc. 2 y art. $2^{\circ}$ del DS 93, según veremos), y que se debe otorgar dentro del plazo de 8 días de recepcionada la factura electrónica, no siendo suficiente para ello, por ejemplo, el sólo envío de un correo electrónico en que se exprese haberla recibido conforme..$^{58}$

\subsection{El acuse de recibo electrónico}

Según lo dispone el art. $2^{\circ}$ del DS 93: "Tratándose de facturas electrónicas, el recibo de la recepción de las mercaderías o servicios podrá constar en un acuse de recibo electrónico emitido por un receptor electrónico autorizado por el Servicio de Impuestos Internos de acuerdo con el formato definido por éste, o

\footnotetext{
${ }^{57}$ En tal sentido, vid. n. 46 de este trabajo.

${ }^{58}$ En tal sentido, Corte Suprema, 19 de mayo de 2015, "Apia S.A. con Constructora Tipaume S.A.”, Rol 1073-2015, considerando 3: "Que en lo que atañe al cuestionamiento de la recurrente, la sentencia censurada ha dejado asentados, como hechos de la causa, que en las facturas electrónicas acompañadas no consta el acuse de recibo de las mercaderías y/o los servicios prestados y que no existen guías de despacho en las que pudiera constar ese antecedente. Asimismo, analizando lo preceptuado por el artículo $9^{\circ}$ de la Ley $N^{\circ} 19.983$ y el artículo $2^{\circ}$ del Decreto Supremo $N^{\circ} 93$, del año 2005, atendida la naturaleza electrónica de las facturas que fundan la ejecución, los jueces también determinan que del análisis de la prueba rendida no se aprecia el acuse de recibo exigido por tales disposiciones, consideraciones fácticas en virtud de las cuales concluyen que las facturas que pretenden cobrarse por esta vía de apremio carecen de mérito ejecutivo".
} 
por escrito en una o más guías de despacho no electrónicas o representaciones impresas de guías de despacho electrónicas o de facturas electrónicas".

Esto ha dado pie a la jurisprudencia para admitir que el acuse de recibo, que conforme lo prescribe el art. 4 b) se requiere tanto para que la copia de la factura quede apta para su cesión, como para otorgarle mérito ejecutivo (art. 5 c), puedan otorgarse tanto en forma electrónica como en forma manuscrita sobre una copia impresa de la factura electrónica. En tal sentido se ha fallado: ${ }^{59}$ “... cabe tener presente que la factura que se cobra en autos fue emitida electrónicamente, por lo que para resolver el asunto jurídico planteado en el arbitrio en estudio es imprescindible exponer lo dispuesto en el artículo 9 de la Ley $N^{\circ} 19.983$ que en lo pertinente señala: "Las normas de la presente ley serán igualmente aplicables en caso que la factura sea un documento electrónico emitido de conformidad a la ley por un contribuyente autorizado por el Servicio de Impuestos Internos. En tal caso, el recibo de todo o parte del precio o remuneración deberá ser suscrito por el emisor con su firma electrónica, y la recepción de las mercaderías o servicios que consten en la factura podrá verificarse con el acuse de recibo electrónico del receptor. No obstante, si se ha utilizado guía de despacho, la recepción de las mercaderías podrá constar en ella, por escrito, de conformidad con lo establecido en esta ley". Lo expuesto en la norma transcrita se relaciona directamente con lo dispuesto en el artículo 5 de la ley, que dispone que la copia cedible de la factura tendrá mérito ejecutivo para su cobro, si cumple los siguientes requisitos que se describen, entre ellos figura el de la letra c), que exige que en el referido instrumento conste el recibo de las mercaderías entregadas o del servicio prestado, con indicación del recinto y fecha de la entrega de las mercaderías o de la prestación del servicio e identificación de la persona que recibe las mercaderías o el servicio, más la firma de este último. Asimismo, conviene tener presente lo que dispone el Decreto Supremo $N^{o}$ 93, publicado en el Diario Oficial el 13 de abril de 2005 que aprueba el Reglamento para la aplicación del artículo $9^{\circ}$ de la Ley $N^{\circ} 19.983$, respecto de la cesión de los créditos contenidos en una factura electrónica, el que define en su artículo $1^{\circ}$, qué se entiende por la misma, indicando que corresponde a "las facturas de venta, facturas de compra, facturas exentas y liquidaciones de factura, generadas como un documento electrónico emitido y firmado por un contribuyente autorizado por el Servicio de Impuestos Internos". Este cuerpo normativo, en su artículo $2^{\circ}$, dispone que: "Tratándose de facturas electrónicas,

${ }_{59}$ Corte Suprema, 3 de marzo de 2016, "BCI Factoring con Fisco de Chile”, Rol 5769-2015, considerando $5^{\circ}$. 
el recibo de la recepción de las mercaderías o servicios podrá constar en un acuse de recibo electrónico emitido por un receptor electrónico autorizado por el Servicio de Impuestos Internos de acuerdo con el formato definido por éste, o por escrito en una o más guías de despacho no electrónicas o representaciones impresas de guías de despacho electrónicas o de facturas electrónicas". ${ }^{60}$

Con todo, y sin perjuicio de lo indicado, la discusión a este respecto pierde actualmente interés, toda vez que por la reforma incorporada en virtud de la Ley 20.956, al art. $4^{\circ}$ inc. $4^{\circ}$, segunda parte, se establece expresamente que: "En caso que el recibo no haya sido efectuado en el plazo señalado y tampoco haya existido reclamo en contra de su contenido o de la falta total o parcial de entrega de las mercaderías o de la prestación del servicio mediante alguno de los procedimientos establecidos en el artículo $3^{\circ}$, se presumirá que las mercaderías han sido entregadas o el servicio ha sido prestado. En este último caso, la factura quedará apta para su cesión, sin necesidad de que el recibo conste en la misma".

Es decir, a partir de la referida modificación, no será condición necesaria para que la factura quede apta para la cesión, estampar el recibo al que se refiere el art. $\left.4^{\circ} \mathrm{b}\right){ }^{61}$ bastando solamente que transcurra el plazo de ocho días corridos siguientes a su recepción, sin que se hubiere reclamado de su contenido, o de la falta total o parcial de entrega de las mercaderías o de la prestación del servicio, por cuanto, al no existir reclamo, se produce el mismo efecto que si quedara irrevocablemente aceptada $\left(\right.$ art. $3^{\circ}$ ) y, por ende, podrá ser cedida y no verá afectado su mérito ejecutivo. Lo anterior, de acuerdo lo establece el nuevo texto de la letra del art. $5^{\circ} \mathrm{c}$ ), según el cual: "La misma copia referida en el artículo anterior tendrá mérito ejecutivo para su cobro, si cumple los siguientes requisitos: c) Que en la misma conste el recibo de las mercaderías entregadas o del servicio prestado, con indicación del recinto y fecha de la

${ }^{60}$ En el mismo sentido: Corte Suprema, 16 de noviembre de 2015, "S.G.C. con Sociedad Comercial REM Ltda.", Rol 8964-2015; Corte de Apelaciones de Santiago, 12 de julio de 2016; "Protab S.A con Servicios Externos Ltda.", Rol 947-2016; Corte Suprema, 6 de mayo de 2014, "Cía. de Seguros de Crédito Continental con MM.CR", Rol 5138-2013; Corte Suprema, 15 de diciembre de 2016, "Protab S.A. con Servicios Externos Ltda.", Rol 499-2016.

${ }^{61}$ Artículo $4^{\circ}$. La copia de la factura señalada en el artículo $1^{\circ}$, quedará apta para su cesión al reunir las siguientes condiciones: b) Que en la misma conste el recibo de las mercaderías entregadas o del servicio prestado, con indicación del recinto y fecha de la entrega o de la prestación del servicio y del nombre completo, rol único tributario y domicilio del comprador o beneficiario del servicio e identificación de la persona que recibe, más la firma de este último. En el evento que se omitiere consignar en el acto de recibo el nombre completo, rol único tributario o domicilio del comprador o beneficiario del servicio, se presumirá que son los que se consignan en la factura. Si se omitiere consignar el recinto de entrega, se presumirá entregado en el domicilio del comprador o beneficiario del servicio señalado en la factura". 
entrega de las mercaderías o de la prestación del servicio e identificación de la persona que recibe las mercaderías o el servicio, más la firma de este último, o que haya transcurrido el plazo establecido en el inciso cuarto del artículo $4^{\circ}$ precedente sin haber sido las facturas reclamadas conforme al artículo $3^{\circ}$ ".

\subsection{La cesión del crédito por medios electrónicos}

Respecto de la regulación particular para la cesión del crédito consagrado en la factura electrónica, el art. 9 inc $2^{\circ}$ Ley 19.983 prescribe, "solamente podrá efectuarse mediante medios electrónicos y se pondrá en conocimiento del obligado al pago de ellas, mediante su anotación en un registro público electrónico de transferencias de créditos contenidos en facturas electrónicas que llevará el Servicio de Impuestos Internos".

Como podemos ver, en esta disposición la Ley abandona la neutralidad tolerada por el ordenamiento y la jurisprudencia a propósito del acuse de recibo (4 b en relación con 5 c, Ley 19.983). En efecto, si la factura es electrónica, la cesión del crédito contenida en ella sólo puede hacerse a través de medios electrónicos por medio del registro público de transferencias que lleva el SII. ${ }^{62}$

Esta norma guarda relación con un aspecto esencial de la circulación de los títulos valores, la seguridad, pero en este caso específico, referido a los documentos electrónicos. Lo descrito, para nosotros, no es sino a partir de la aplicación del principio de equivalencia funcional en virtud del cual los títulos electrónicos deben cumplir funciones equivalentes a las de los documentos en papel.

De acuerdo a la teoría general de los títulos de valores, para este tipo de documentos rige la máxima de "un derecho, un documento", es decir, se debe respetar aquella característica general que nosotros reconocemos bajo el nombre de necesariedad. La singularidad ("uniqueness") de un título valor implica que la disposición sobre un derecho (crédito) con ánimo traslativo se realiza a través de la disposición sobre el papel que lo incorpora, es decir, se presupone y requiera de la singularidad del título, su originalidad, pues sólo así queda garantizado el efecto extintivo que para el transmitente tiene la disposición realizada. ${ }^{63}$

${ }^{62}$ Registro regulado por la Circular 56 del SII, de 27 de noviembre de 2013, que imparte instrucciones sobre cesión de créditos contenidos en una factura electrónica y estableció el procedimiento de anotaciones correcciones o revocaciones de anotaciones en el Registro Público Electrónico de Transferencias de Créditos.

${ }^{63}$ Alba Fernández, Manuel, "Documentos de transporte y negociabilidad en un entorno electrónico 
Lo anterior puede significar un problema tratándose de títulos electrónicos, en que, a diferencia de aquellos que constan en soporte material de papel, se hace más difícil distinguir entre un documento original y una copia,${ }^{64}$ por cuanto, aunque compartamos la opinión ${ }^{65}$ que esta distinción carece de sentido, ya que lo que importa es que el documento tenga la virtud de asegurar autoría e integridad, no podemos soslayar que la singularidad del título, y con ello su aptitud dispositiva, puede verse afectada de no existir un efectivo control sobre su mecanismo de transferencia.

Frente a esta situación, y tal como se ha planteado, ${ }^{66}$ existen dos maneras de entender el problema. Por una parte, se admite que no se puede ostentar documento electrónico (con lo cual desaparece su función representativa del derecho en el incorporado y la disposición de este derecho ya no se efectúa mediante la entrega del título), o bien, se entiende que no obstante ser una cosa intangible, tiene una existencia perceptible por los sentidos y que, más que la presentación física y material del título, la tenencia se efectúa por medio de su acceso y disposición, esto es, por medio del control de documento en su estado binario.

Esta segunda forma de entender el problema separa la noción de tenencia de la de tangibilidad material del documento electrónico, entendiendo éste se ostenta (posee) por medio de su control, y que es esta circunstancia lo que permite efectuar todas las operaciones de la misma forma que lo hace la entrega material del documento en soporte de papel, incluida la disposición del derecho en él incorporado.

De tal forma, la respuesta a este problema es la creación de un sistema de

(primera parte)"; Revista de Derecho Mercantil, 2007, № 263, p. 70.

${ }^{64}$ En tal sentido, Corte de Apelaciones de Santiago, 5 de diciembre de 2014, Rol No 3976-2014, considerando $4^{\circ}$ : "Que el recurrente ha invocado, seguidamente, la causal de casación contemplada en el artículo $768 N^{o} 7$ del Código de Procedimiento Civil esto es, contener la sentencia decisiones contradictorias, lo que a su juicio se manifestaría en que, pese a haberse invocado como títulos unas facturas electrónicas, el fallo aplica la Resolución $N^{o} 14$ de 8 de febrero de 2005, del Servicio de Impuestos Internos referida a la tercera copia y, asimismo, en que no obstante reconocer que en el caso de las facturas electrónicas no es posible identificar primeras, segundas o terceras copias, el Tribunal a quo considera exigible en ellas un recuadro que sólo resulta pertinente para las facturas de papel". (el destacado es nuestro).

${ }^{65}$ Canelo, Carola; Arrieta, Raúl; Moya, Rodrigo; Romo, Rodrigo, "El Documento Electrónico. Aspectos Procesales", Revista Chilena de Derecho Informático, 2004, N 4, p. 88. Los autores llegan a la anterior conclusión luego de afirmar que, si nos enfocamos en el original puro, solo nos podríamos referir a las huellas insertas en la memoria RAM del computador, que por ser volátil, termina volcándose en el disco duro que sería realmente el original, ubicación que, al ser poco operativa, debe ser sustituida por otros soportes como el CD, DVD u otros.

${ }^{66}$ Barroilhet Acevedo y Basso Cerda, cit. (n. 38), p. 190. 
asignación de titularidades, pero ya no basado en la posesión del título como sería para la teoría tradicional de los títulos valores, sino que en un sistema basado en la noción de control sobre el documento, lo que se logra mediante la creación de un registro centralizado, y esto es, en nuestra opinión, lo que justifica a la norma del art. $9^{\circ}$ inc. $2^{\circ}$ que, como hemos visto, no admite como equivalente funcional para la factura electrónica, el mecanismo de cesión consagrado en los artículos $7^{\circ}$ y $8^{\circ}$ de la Ley 19.983. Entendemos esta es la manera correcta como podemos conciliar las normas de los recién referidos artículos, que requieren la tenencia material de la factura y, por otro, la norma del art. $9^{\circ}$ de la Ley 19.983, que permite reconocer a la factura electrónica en virtud de la aplicación de la equivalencia funcional, igual validez, eficacia y seguridad jurídica, que a su equivalente tradicional al momento de transferir el derecho en ella incorporado.

\section{CONCLUSIONES}

La factura electrónica se presenta para el Ordenamiento como un equivalente funcional de su símil en papel, toda vez que la estructura técnica aportada por el SII, y la regulación otorgada por el legislador, permiten a este instrumento cumplir análogas funciones en el tráfico mercantil, que las desempeñadas hasta ahora por los títulos tradicionales.

La sustitución del soporte, que a partir de la Ley 20.027 consiste en una representación telemática del documento, no afecta de modo alguno las facultades probatorias, constitutivas y dispositivas de las que se reviste a la factura, si la consideramos un título valor tal como lo ha reconocido nuestra doctrina y jurisprudencia.

Desde el punto de vista de nuestro análisis de la normativa, y al tenor de las disposiciones de la Ley 19.983 (después de las sucesivas modificaciones que ha experimentado) y el D.S. 93, observamos que las mismas gestiones que sobre la copia cedible de la factura tradicional se requieren para: fijar su texto y la relación jurídica fundamental que en ella consta; configurar su mérito ejecutivo por medio de la gestión preparatoria regulada en la Ley; y para cederla en propiedad o en comisión de cobranza, deben cumplirse respecto de la factura electrónica, sin perjuicio que en este último caso se debe respetar algunas particularidades que se derivan del cambio de soporte, como es, principalmente, el hecho que la cesión del crédito contenido en ella sólo pueda realizarse por medios electrónicos, con respeto a las formas que ordena el procedimiento especialísimo que se ha creado a tal efecto. 


\section{BIBLIOGRAFÍA}

Alba Fernández, Manuel, "Documentos de transporte y negociabilidad en un entorno electrónico (primera parte)"; Revista de Derecho Mercantil 2007, N²63, pp. 69-114.

Alba Fernández, Manuel; García Mandaloniz, Marta; Rodríguez de las Heras Ballell, Teresa, "Electronificación de Instrumentos de Transporte Aéreo de Mercancías: El Proyecto E-Freight", Derecho de los Negocios (Madrid), 2006, $\mathrm{N}^{\circ} 184$, pp. 23-32.

Barroilhet Acevedo, Claudio; Basso Cerda, Osvaldo, Conocimiento de Embarque Electrónico, Librotecnia, Santiago, 2005.

Caballero Germain, Guillermo, La custodia en el mercado de valores. De los títulos de crédito a los valores anotados en cuenta, Thomson Reuters, Santiago, 2016.

Canelo, Carola; Arrieta, Raúl; Moya, Rodrigo; Romo, Rodrigo, "El Documento Electrónico. Aspectos Procesales", Revista Chilena de Derecho Informático, 2004, № 4, pp. 81-106.

Contreras Strauch, Osvaldo, "Aspectos probatorios de la contratación electrónica”, en De la Maza G., I. (coord.), Derecho y Tecnologías de la Información, Universidad Diego Portales, Fundación Fernando Fueyo Laneri, Santiago, 2002.

Cruz Rivero, Diego, Eficacia formal y probatoria de la firma electrónica, Marcial Pons, Madrid, 2006.

Escobar S., Maximiliano; Hoyuela Z., Camila, "La factura. Un análisis sustantivo del título al tenor de la ley 19.983 y sus modificaciones", Revista de Derecho Universidad de Concepción, 2016, № 240 (Jul-dic), pp.7-40.

Illescas Ortiz, Rafael, "La Equivalencia Funcional como Principio Básico del Derecho de la Contratación Electrónica", Revista Aranzadi de Derecho y Nuevas Tecnologías (Thompson Aranzadi - Navarra), 2003, $\mathrm{N}^{\circ} 1$, pp. 19-31.

Illescas Ortiz, Rafael, "Los Principios de Contratación Electrónica Revisitados", en Madrid Parra, A.; Guerrero Lebrón, M. (coords.), Derecho Patrimonial y Tecnología, Marcial Pons, Madrid, 2007, pp. 21-38.

Illescas ORTIz, Rafael, Derecho de la Contratación Electrónica, Civitas Ediciones, Madrid, 2009, $2^{\mathrm{a}}$ ed.

Madrid PARRA, Agustín, "EDI (Electronic Data Interchange): Estado de la Cuestión en Uncitral”, Revista de derecho mercantil (Madrid) 1993, № 207, pp. 115-150.

Madrid Parra, Agustín, "El Convenio de Naciones Unidas sobre 
Contratación Electrónica", en Madrid Parra, A.; Guerrero Lebrón, M. (coords.), Derecho Patrimonial y Tecnología, Marcial Pons, Madrid, 2007, pp. 39-116.

Prado Puga, Arturo, "Alcance jurídico de la factura como título de circulación mercantil", Revista de Derecho P. Universidad Católica de Valparaíso, 2016, Vol. XLVI, pp. 155-189.

Recalde Castells, Andrés, El Conocimiento de Embarque y otros Documentos del Transporte, Función Representativa, Civitas, Madrid, 1992.

Recalde Castells, Andrés, "Electronificación de los títulos-valor", en: Fernández Ordóñez, M.; Cremades García, J.; Illescas Ortiz, R. (coords.), Régimen Jurídico de Internet, Editorial La Ley, España, 2001, pp. 569-606.

Rico Carrillo, Mariliana, "El Tratamiento Electrónico de los Títulos Valores", Revista de Contratación Electrónica (Cádiz), 2002, № 24, pp. 21-46.

Sandoval LóPez, Ricardo, Derecho Comercial, Teoría General de los Títulos de Crédito, Letra de Cambio, Pagaré, Cheque y Títulos Electrónicos o Desincorporados, Editorial Jurídica de Chile, Santiago, 2001. $5^{\text {a Ed. }}$

Sandoval López, Ricardo, "Principios que informan el derecho del comercio electrónico", Revista de Derecho Universidad de Concepción, 2001, $\mathrm{N}^{\circ} 210$, pp. 169-184.

SAndoval López, Ricardo, Derecho del comercio electrónico, análisis de la ley 19.799, sobre documentos electrónicos, firma electrónica y servicios de certificación de dicha firma, Editorial Jurídica de Chile, Santiago, 2003, 1ª Ed.

Sandoval López, Ricardo, Derecho Comercial. Tomo II, Teoría General de los Títulos Valores, Editorial Jurídica de Chile, Santiago, 2015.

Tena, Felipe de J., Títulos de Crédito, Editorial Porrúa, México, 1956.

NORMATIVA CITADA

Ley 19.799 de 2002, sobre documentos electrónicos, firma electrónica y servicios de certificación de dicha firma, D. Oficial de 12 de abril de 2002.

Ley 19.983 de 2004, regula la transferencia y otorga merito ejecutivo a copia de la factura, D. Oficial de 15 de diciembre de 2004.

Ley 20.219, destina recursos para el Fondo de Desarrollo de la Región de Magallanes y de la Antártica chilena y modifica otros cuerpos legales que indica, D. Oficial de 3 de octubre de 2007.

Ley 20.323, modifica la Ley $\mathrm{N}^{\circ} 19.983$ con el objeto de facilitar la factorización de facturas por pequeños y medianos empresarios, D. Oficial de 29 de enero de 2009.

Ley 20.727, introduce modificaciones a la legislación tributaria en ma- 
teria de factura electrónica y dispone otras medidas que indica, D. Oficial de 31 de enero de 2014.

Ley 20.956, establece medidas para impulsar la productividad, D. Oficial de 26 de octubre de 2016.

Decreto Ley $\mathrm{N}^{\mathrm{o}} 825$, sobre Impuesto a las Ventas y Servicios, D. Oficial de 31 de diciembre de 1974.

Resolución Exenta $N^{\circ} 45$ del SII, de 1 de septiembre de 2003, estableció normas y procedimientos de operación respecto de los documentos tributarios electrónicos.

Resolución Exenta $N^{\circ}$ 14, del SII, de 8 de febrero de 2005, estableció normas y procedimientos de operación respecto de los documentos tributarios electrónicos.

Decreto Supremo № 93 del Ministerio de Hacienda, de 13 de abril de 2005, aprobó el reglamento para la aplicación del art. $9^{\circ}$ de la Ley 19.983, respecto de la cesión de los créditos contenidos en una factura electrónica.

Circular $N^{\circ} 56$ del 27 de noviembre de 2013 del SII, impartió instrucciones sobre cesión de créditos contenidos en una factura electrónica y estableció el procedimiento de anotaciones correcciones o revocaciones de anotaciones en el Registro Público Electrónico de Transferencias de Créditos.

Ley Modelo Sobre Comercio Electrónico de UNCITRAL (LMUCE), aprobada por resolución 51/162 de la Asamblea General de Naciones Unidas el 16 de diciembre de 1996, disponible en página web de la Comisión de las Naciones Unidas para el Derecho Mercantil Internacional, www.uncitral.org.

Convención de las Naciones Unidas sobre la Utilización de las Comunicaciones Electrónicas en los Contratos Internacionales (CNUUCECI), aprobada por resolución 60/21 de la Asamblea General de Naciones Unidas el 23 de noviembre de 2005, disponible en página web de la Comisión de las Naciones Unidas para el Derecho Mercantil Internacional, www.uncitral.org.

Real Decreto-Ley 14/1999 [España] de 17 de septiembre de 1999 (RCL 1999, 2379), sobre firma electrónica (BOE. N ${ }^{\circ} 224$ de 18 de septiembre de 1999).

SENTENCIAS CITADAS

Corte Suprema, 7 de diciembre de 2010, "Sociedad de transporte Latino Kunstmann Ltda. con Sociedad Frutos del País Frías y Quera Limitada", Rol 7217-2009.

Corte Suprema, 7 de diciembre de 2010, "Hidromecánica y Estructuras 
Integrales con Óscar Azócar Larenas y Compañía Ltda.”, Rol No 6469-2009.

Corte Suprema, 29 de diciembre de 2010, "Morales Villegas, Hernán con Veterquímica Limitada", Rol 6470-2009.

Corte Suprema, 27 de enero de 2011, "CFC Capital S.A. con Veolía Water System Chile Limitada”, Rol 9139-2009.

Corte Suprema, 21 de septiembre de 2011, "Interfactor con Sindelen", Rol 3239-2010.

Corte Suprema, 1 de diciembre de 2011, "Chile Factoring S.A. con Fernando Mayer Construcciones S.A.”, Rol 3117-2011.

Corte Suprema, 6 de mayo de 2014, "Cia. de Seguros de Crédito Continental con MM.CR", Rol 5138-2013.

Corte de Apelaciones de Santiago, 5 de diciembre de 2014, "Apia S. A. con Sociedad Constructora ALCA Ltda.”, Rol N 3976-2014.

Corte Suprema, 19 de mayo de 2015, "Apia S.A. con Constructora Tipaume S.A.”, Rol 1073-2015.

Corte Suprema, 16 de noviembre de 2015, "S.G.C. con Sociedad Comercial REM Ltda", Rol 8964-2015.

Corte Suprema, 3 de marzo de 2016, "BCI Factoring con Fisco de Chile", Rol 5769-2015.

Corte de Apelaciones de Santiago, 12 de julio de 2016; "Protab S.A. con Servicios Externos Ltda.”, Rol 947-2016.

Corte Suprema, 15 de diciembre de 2016, "Protab S.A. con Servicios Externos Ltda.”, Rol 499-2016.

Corte de Apelaciones de San Miguel, 21 de agosto de 2017, "Taciones (sic) y asesorías con Manufacturas Interamericanas", Rol 843-2017. 